\title{
Open Access Broadband Networks in Alberta, Singapore, Australia and New Zealand
}

\author{
Jock Given, Swinburne University, Melbourne \\ Catherine Middleton, Ryerson University, Toronto
}

Paper presented at the 2010 Telecommunications Policy Research Conference.

\begin{abstract}
In policy debates about the appropriate regulation of next generation fibre access networks, a good deal of attention has been paid to various forms of 'separation' between network, wholesale and retail operations. This discussion is no longer theoretical, because 'open access' next generation networks are now operating or being constructed. This paper investigates four different models around the world, each at different stages of deployment:

- Alberta, Canada, where a commercial company Axia has been operating the provincewide 'SuperNet' since 2005. This is an optic fibre network connecting 4700 sites (provincial government and municipality offices, health and education sites, libraries) in 27 urban and 402 rural communities. Axia is the government's service provider across the whole network and the wholesaler of capacity to retail providers in the rural communities.

- Singapore, where a network is under construction taking fibre to 1.12 million residential premises and 152,000 other premises. Separate companies are building the physical infrastructure ('Net Co') and installing the electronics and network termination devices in customer premises and operating the network ('Op Co').

- Australia, where a national FTTP network is being built to reach 93\% of households and businesses. Wireless will be used to deliver download speeds of at least $12 \mathrm{Mbps}$ to the other 7\%. Around 200,000 households will get FTTP in Tasmania, where services commenced in mid-2010.

- New Zealand, where the national government has promised 'superfast broadband' within six years to all businesses, schools and health services, greenfields developments and some residential users, and to $75 \%$ of the population within ten years.
\end{abstract}

Drawing on interviews conducted in the four territories in 2009 and 2010, the paper will investigate the common, contrasting and unique features of these four models. 


\section{Introduction}

In policy debates about the appropriate regulation of next generation fibre access networks, a good deal of attention has been paid to various forms of 'separation' between network, wholesale and retail operations. This discussion is no longer theoretical, because 'open access' next generation networks are now operating or being constructed.

This paper investigates four different models around the world, in the Canadian province of Alberta, Singapore, Australia and New Zealand. Each is at a different stage of deployment. Drawing on interviews conducted in the four territories in 2009 and 2010, the paper investigates the common, contrasting and unique features of these four models. It makes very preliminary assessments of the strengths and weaknesses of the four models, acknowledging the difficulty of doing so at a point when only one, in Alberta, has been delivering services for any length of time.

The research is being undertaken as part of a research project 'Developing Next Generation Broadband Infrastructure: learning from Australia's national broadband network', funded in 2009/10 by the Social Sciences and Humanities Research Council, Canada's federal funding agency for university-based research and student training in the social sciences and humanities.

\section{Context and overview of the models}

Details of the four models are set out in the Table (found after the References section of this paper).

\section{Alberta, Canada - the 'SuperNet'}

The Canadian case study differs from the others for two main reasons. First, it is a regional (province-wide) rather than a national initiative. Second, the next generation infrastructure does not extend directly to residential or business premises. Located in Western Canada, the province of Alberta is approximately the size of France. Approximately $75 \%$ of the population of 3.8 million lives in seven urban centres, primarily in free-standing houses. The rest are widely dispersed throughout the rural and remote regions of the province. A portion of revenues from the exploitation of the province's rich natural resources goes to the Alberta Heritage Fund, a source of finance or government programs unique among Canadian provinces.

In 2000, seeking to foster economic development, the province announced plans to build a fibre optic network to serve the entire province. The flowing year, the Alberta SuperNet (www.thealbertasupernet.com) was created as a public-private partnership between the Government of Alberta, and private companies Bell Canada and Axia NetMedia. Built "to enrich the life of all Albertans," the SuperNet was intended to extend broadband connectivity throughout the province, and enable improved government service delivery (Alberta SuperNet, 
2010a). The total cost was at least C $\$ 330$ million (US\$313.5 million at September 2010 exchange rates).

The SuperNet was designed to provide all Albertans, regardless of their location, with access to government services, and to help provide high speed internet access across the province. It comprises a direct fibre connection to more than 4700 government facilities (including provincial government and municipality offices, health and education sites, libraries), enabling a wide range of government services to be delivered into local communities (Alberta SuperNet, 2006). Axia has a ten-year renewable contract with the government to provide the broadband connectivity that enables these services. The government acts as an anchor tenant for the SuperNet, and is committed to spend a significant though undisclosed amount each year buying services. Axia is also the wholesaler of services to third party service providers on the Supernet. The network provides a point of presence (POP) in $402 \mathrm{rural} /$ remote communities. Any approved service provider can request access to the SuperNet at a POP (Alberta SuperNet, 2010b). Pricing for service is uniform across the province. Axia does not act as a retail provider except in its role as a provider of services to the government.

Like other next generation networks, the SuperNet does not simply deliver 'the internet'. It is a private network (described as 'just a pipe'), supporting connections between any points on the network. The SuperNet can act as a 'middle mile' to aggregate traffic from anywhere on its fibre optic network to a central location ('meet me' point) where it can be connected to the internet or other services. It is this functionality that allows internet service providers (ISPs) to extend broadband connectivity into any SuperNet community, but the service provider must also provide infrastructure from the SuperNet POP to the customer premise. About 300 communities have at least one service provider accessing the SuperNet at the local POP, but this does not necessarily mean that residential internet services are available in that community.

\section{Singapore - the Next Generation National Broadband Network}

Singapore is an island state, with a land area just greater than $700 \mathrm{~km}^{2}$. It has a population of about 5.1 million, approximately $85 \%$ of whom live in multi-unit dwellings. Singapore has had good broadband connectivity for many years, with uptake rates close to the OECD average. In 2006, as part of a broader exercise about the future development of ICTs in Singapore, an advisory committee recommended the deployment of an open access fibre-optical network that would provide gigabit speeds to all homes, schools and businesses (FTTP) in the country, replacing the copper/HFC infrastructure already in use. It also recommended the parallel development of a "pervasive nation-wide wireless broadband network to meet the access needs of individuals everywhere and everytime" (iN2015 Infocomm Infrastructure Services and Technology Development Sub-Committee, 2006, p. 6 and see Infocomm Development Authority of Singapore (2010a) for details on Singapore's wireless network Wireless@SG.). The potential benefits of establishing such infrastructure were clearly articulated by the committee, and include new applications and improved services to support commerce, learning, healthcare, digital media and entertainment (Infocomm Development Authority of Singapore, 2010b). 
Initial planning for a public-private partnership to build and operate Singapore's next generation national broadband network (NGNBN) began in 2006 (Infocomm Development Authority of Singapore, 2006). In 2007, it was announced that the network would be built with structural separation between the passive and active network infrastructure, and operational separation between the active infrastructure and the services layer (see Infocomm Development Authority of Singapore, 2009b). In 2008, the 'NetCo' contract to build the network was awarded to OpenNet (Yang, 2008), and in 2009, Nucleus Connect was awarded the 'OpCo' contract to install the active electronic components (Infocomm Development Authority of Singapore, 2009a). The NGNBN is now under construction, taking fibre to 1.12 million residential premises and 152,000 other premises.

The Singaporean government will invest up to S\$1 billion (US\$742 million at September 2010 exchange rates ) in the project by providing grants of up to $\mathrm{S} \$ 750$ million to OpenNet and up to S\$250 million to Nucleus Connect. By September 2010, OpenNet covered more than $40 \%$ of Singaporean homes and businesses. $60 \%$ will be covered by December 2010 and $95 \%$ by mid2012 (OpenNet, 2010). Nucleus Connect has activated the network, and five retail service providers are ready to launch services (Nucleus Connect, 2010).

\section{Australia - the National Broadband Network (NBN)}

A plan for broadband was one of the first major policies announced by new Australian Labor Opposition leader Kevin Rudd in March 2007. (ALP 2007) Capitalising on the perceptions that Australia was lagging the developed world in the take-up of fixed line broadband, the technical opportunity offered by next generation fixed line access networks, widespread criticism of the incumbent Telstra's continuing power and refusal to invest in a fibre access network without regulatory change, large budget surpluses and an election focus on policies for the future, Rudd promised to inject \$A4.7 billion of public money into a National Broadband Network. It would bring speeds of $12 \mathrm{Mbits} / \mathrm{sec}$ to $98 \%$ of Australians via an upgrade of the fixed line network to FTTN or FTTP. This first plan for revived public investment provided a policy bridge away from Labor's opposition to privatizing Telstra.

Telstra's stalled plans to upgrade its fixed network to FTTN were at the centre of the fracas that led to Labor's new policy. A 2005 plan to deliver initial speeds of $6 \mathrm{Mbits} / \mathrm{sec}$ to $99 \%$ of metropolitan customers and $94 \%$ of rural customers, later modified to offer faster speeds but only in the major cities, was referred by the government to the competition regulator. Telstra wanted relief from the special telecommunications competition regime before investing. Discussions broke down, but these plans provided the basis for the Labor Opposition's 2007 national broadband plan. (Campbell and Holmes 2008) The Government announced a cheaper plan of its own, covering WiMAX and ADSL2+ local access and fibre backhaul in nonmetropolitan areas rather than the whole country. A tender was won by a joint venture between Singtel/Optus and rural group Elders, but the contract was terminated by the Labor government elected in November 2007.

The new government commenced another tender process for its own plan, an FTTN or FTTP network offering $12 \mathrm{Mbits} / \mathrm{sec}$ to $98 \%$ of the population. A number of bids were received 
including one from Telstra that was ruled ineligible because it failed to comply with one of the specifications. (Fletcher: 204-7) Faced with a policy framed around an old plan to upgrade the incumbent's network and a list of bidders that now did not include that incumbent, this process too was terminated in April 2009, and replaced with the still more ambitious FTTP plan, to cost an estimated A \$43 billion. (Conroy 2009) By committing to build a fibre access network that would completely replicate the incumbent's copper one, the new plan allowed the Government to claim its new enterprise would be building the national broadband network itself, although it was also widely perceived as a strategy to force the incumbent Telstra into some form of accommodation.

A state-owned company to build and operate the fibre and wireless networks, NBN Co, was formed in 2009. It began designing and building the fibre access network in the island state of Tasmania, in conjunction with the state-owned power utility there. Retail services were first offered in mid-2010. Further trial sites on the mainland were also chosen and the government let a $\$ 250$ million contract to build competing backhaul on some major non-metropolitan routes. The NBN was a major issue dividing the two main parties in the August 2010 election campaign. The opposition proposed a much cheaper strategy similar to the one it was in the process of deploying before it lost office in 2007. The Government did not win enough seats to govern in its own right but secured the support of several independents and a Green Party member in Tasmania, sufficient for a minority government. Broadband policy was cited by the final two country independents as a crucial factor that led them to support Labor rather than the (Conservative) coalition.

\section{New Zealand - the Ultra-Fast Broadband Initiative (UFB)}

Having maintained a state-owned domestic telecommunications monopoly like so many countries through the $20^{\text {th }}$ century, New Zealand created one of the most open telecommunications markets in the world in the late 1980s. All legal restrictions on entry into local telecommunications services markets were removed in 1989 and the incumbent Telecom was privatized a year later. (MED 2001) No specialist regulator was created; reliance was initially placed on general competition law and the courts. A local loop interconnection dispute between entrant Clear Communications and the incumbent Telecom ended up in the Privy Council. (Blanchard 1995)

A telecommunications-specific access regime and Commissioner were created in 2001 and the Commission got new powers to enforce it and to cost and monitor Telecom's expanded public service obligations, previously known as the 'Kiwi Share'. Amendments in 2006 further strengthened the Commission's and the Minister's powers, providing tools for local loop unbundling and the operational separation of Telecom into discrete, though still commonlyowned, network, wholesale and retail enterprises in 2008. (Commerce Commission 2009a, 2008; Gattung 2010)

As part of the process of functional separation, Telecom agreed to carry out a program of 'cabinetization', or FTTN, through its now separated network arm, Chorus. It is upgrading exchanges, installing 3,600 roadside cabinets fed by 2,500 kilometres of new fibre and deploying 
ADSL2+ over the copper lines between these cabinets and customer premises. This is bringing fixed broadband download speeds of $10-20 \mathrm{Mbps}$ to the 80 per cent of New Zealanders that live and work in towns with 500 or more lines by the end of 2011. (Chorus) By May 2010, half of these cabinets had been installed. (Ratcliffe 2010)

The Labour Government established large spending programs to support better rural broadband, believing its changes to the structure of Telecom and industry regulation would not be enough to get better broadband to all New Zealanders. But as in Australia, the Opposition trumped these targeted initiatives with a bigger plan in April 2008 (Key 2008), promising superfast broadband within six years to all businesses, schools and health services, greenfields developments and some tranches of residential users, and to $75 \%$ of population within ten years. A state-owned enterprise, Crown Fibre Holdings, would be created to invest up to a half-share in 33 Local Fibre Companies (LFC's) serving designated areas. Parties were selected for 'prioritised negotiation' in three areas in early September 2010.

\section{Analysis}

The four examples investigated are all places where governments concerned about the quality and cost of broadband services have decided to invest in new fixed line infrastructure. All have established state-owned enterprises or partnerships between the public and private sectors to build and operate 'open access' fibre networks. The aim is to upgrade fixed line infrastructure and operate it in a different way from either the old era of state-owned monopolies or the more recent era of privatized, vertically integrated telcos.

The populations of three of the four places are small, 4-5 million. Only Australia's is greater than 20 million. Three are nation states and the other, Alberta, is a province of a nation state. Singapore and New Zealand have no provincial level of government so only the national government has the policy, legislative, regulatory and financial capacity to carry out ambitious broadband plans. In Australia and Canada, although provincial governments have been increasingly involved in communications, the national governments carry primary responsibility for communications policy and law and have much larger budgets. Alberta's action on broadband has been partly motivated by frustration about lack of national government action.

The earliest of the current wave of publicly-supported fibre networks was Alberta's, announced in 2001 and completed in 2005. It is also the least costly, both in total size and per head of population. Later plans are larger by both measures, spectacularly so in Australia's case. The total public cost of its National Broadband Network is around 34 times the amount per head initially committed in Alberta, 12 times Singapore's, and 7 times New Zealand's, although these calculations use only the headline expenditure estimates. Alberta has also recently announced a new plan to spend extra money supporting 'last mile' infrastructure in the nearly $40 \%$ of rural and remote communities where it still does not exist five years after the completion of the initial SuperNet project. 


\section{Rationales}

The earliest of the plans, in Alberta, aimed to encourage connection of rural communities currently without broadband access and provide government services and information online throughout the province through public agencies. Singapore's was part of an aggressive bid to make the small nation a world leader in information and communications technologies requiring high quality fixed and wireless coverage across the whole island.

Coming later, the New Zealand and Australian plans responded to a perception that these countries were lagging the world in broadband. Both were well behind the OECD average for total broadband subscribers per 100 inhabitants in the early 2000s. Australia passed the OECD average for the first time in 2005, New Zealand in the second quarter of 2009. (OECD 2009b: Table 4.9) But prices are still high and, like only two other OECD countries in October 2008, bit caps were universal (OECD 2009a), although there have been big increases in download limits in 2009-10. The goal of both plans is not just faster download and upload speeds but also structural change. Investing directly in FTTP networks would enable governments to dictate the way they are operated more directly than legislated access regimes. 'Open access' and wholesale-only operation would be the infrastructure owner's choice, rather than one the regulator tries to impose. Big national plans also provided an opportunity for governments to reshape public and industry discussion about telecommunications, especially in sectors outside the traditional communications business-the so-called 'trans-sector' agenda.

The global financial and economic crisis encouraged government spending, especially on infrastructure that could yield a 'double-dividend' by raising aggregate demand in the short-term and aggregate supply in the long-term. (OECD 2009c: 163-78; Reynolds 2009) All-fibre access networks were presented as 'future-proof', the 'final destination' rather than an intermediate step, like the FTTN networks Telecom (NZ) was building and Telstra (Australia) was planning. 'Going beyond fibre optic to the node to fibre optic to the premises is the right way to go,' said the Australian Prime Minister. (Rudd and Swan, 2009) 'You do it once, you do it right and you do it with fibre,' said one of two country independents on whose support the new minority Labor Government's majority depends. (White 2010) Finally, building FTTP rather than FTTN strengthened governments' hands in negotiations with the incumbents, because it enabled them to argue that the state could go ahead without them. In practice, the role of the incumbents in the new plans has been critical everywhere, as discussed further below.

\section{What is being done}

Radically different geographies and population densities make the task of building fibre networks in these four places and the cost per head very different. Partly reflecting this, governments have chosen to do different things. Singapore has been the most ambitious, promising almost universal FTTP coverage for homes and businesses on the island by 2012, as well as basic wireless coverage $(1 \mathrm{Mbit} / \mathrm{sec})$ in public areas. Australia is promising close to universal fibre coverage of homes and businesses by 2018, but the spread of population across a huge landmass still leaves a large role for fixed wireless and satellite for the $7 \%$ that fibre will not reach. New Zealand's fibre coverage goal is lower and slower but priority is being given to institutions like schools and hospitals. Alberta's original focus on backbone infrastructure and 
government service delivery is now being supplemented by the proposed investment in 'last mile' wired or wireless infrastructure to provide broadband to more than $10 \%$ of Albertans who currently only have dial up access.

\section{Institutional structures}

Choosing to do different things, the four governments also chose different institutional structures. Alberta and New Zealand chose different structures for parts of their territories, whereas Singapore and Australia chose unified structures. Rather than awarding the SuperNet contract to provincial incumbent Telus, Alberta selected a partnership between Bell Canada (the incumbent in much of Eastern Canada) and newcomer Axia NetMedia. Bell built and owns a fibre backbone in the urban 'base area' and acted as contractor to build the government-owned fibre backbone in the rural 'extended area'. Axia manages private sector access to the entire network, and was also chosen to be the provider of government services and information across the whole network including the base and extended areas.

New Zealand established a single Crown-owned (or state-owned) corporation to invest in partnerships with up to 33 local fibre companies that will build, operate and sell wholesale access services over fibre networks. The final number may be smaller if successful bidders aggregate adjacent areas. CFH first runs the selection process then manages and monitors the Crown's investment in the selected local fibre companies. On 9 September, 14 parties were shortlisted for further negotiation, of which three were selected for 'prioritised negotiation', covering Timaru on the South Island, Whangarei in the north of the North Island and several other centres on the North Island including Hamilton, Tauranga, New Plymouth and Wanganui. Of the parties that bid for all 33 areas, Telecom was shortlisted but Canadian-based Axia NetMedia was not. CFH said its bid 'included certain elements that were not part of the Government's UFB policy'. (CFH 2010b)

Singapore chose the purest but most complex form of structural separation, presented as a threetiered pyramid. At the base, a network company (OpenNet) owns the fibre; in the middle, an operating company (Nucleus Connect) activates it and sells wholesale capacity to the retail service providers at the top of the pyramid, who sell services to residential and business customers. The ownership of the network and operating companies complicates the structure, because incumbents have large roles. OpenNet is controlled by the state-controlled incumbent telco, Singtel, the main newspaper group and power company, and one outsider, Axia. Notably, Axia is participating in the network company in Singapore, whereas it is the operating entity in Alberta. Nucleus Connect is controlled by the cable TV incumbent, StarHub.

Australia, so far, has established a wholly state-owned National Broadband Network Company (NBN Co) to both build and operate the fibre network - the base and the middle of the Singapore pyramid. NBN Co wholly owns a Tasmanian subsidiary which is undertaking the same functions in the small island state where fibre construction commenced. 


\section{Services and pricing}

The wholesale providers Axia in Alberta and Nucleus Connect in Singapore both offer Layer 2 and Layer 3 services. NBN Co in Australia will offer Layer 2 services though there has been some discussion of offering Layer 3 services in limited circumstances. The LFCs in New Zealand were initially to offer only Layer 1 'dark fibre' services. Following changes announced recently, they must provide Layer 2 services across all parts of network plus Layer 1 point-topoint services (particularly suitable for business customers) to end-users seeking premium quality services (likely up to 1 Gbps). Until Dec 2019, they will have to supply services on a non-discriminatory basis. After Dec 2019, they will be required to provide unbundled access to Layer 1 point-to-point services on 'equivalence of inputs' basis. It was decided that requiring unbundled access earlier than this might unduly constrain the LFCs incentive to build their networks. (NZ Government 2010)

Alberta, Australia and - unsurprisingly given its geography - Singapore, all require identical wholesale prices to be set across the entire fibre footprint. Access prices have not yet been set for the Australian NBN but it is stressed that the access price 'holiday' currently in place for the first retail services in Tasmania should not be seen as a precedent for the rest of the network. New Zealand, by contrast, is establishing 'a period of regulatory forbearance from Commission intervention on fibre pricing'. Access prices in the different local fibre areas will be set under the competitive tendering process for the UFB rather than by the regulator. Because networks have not yet been built, it has been decided that builders have the right to expect that the prices that are set in contract will not be overridden by regulation for the initial period (to 2019). Copper will continue to be regulated 'and exercise significant competitive constraint on fibre pricing'. (NZ Government 2010)

\section{Role of incumbent organizations and infrastructure}

The role of incumbent fixed line operators in the new fibre broadband plans has been critical. The public plans for fibre access networks were not just about faster speeds but about ensuring the new networks were not operated as part of vertically integrated businesses. In Alberta, many interpreted the whole concept of a government-supported fibre backbone as a strategy to encourage a fixed line entrant into the province to compete with the incumbent Telus. In Singapore, the three-tiered structural separation was designed to work with whoever the successful bidders were. In practice, telco, cable TV, power utility and press incumbents have all been given roles in either the NetCo or OpCo.

In New Zealand, the UFB has also 'been designed from the beginning to be supplier neutral'. (NZ Government, 2010) The same rules would apply to Telecom or other players whoever is successful. The Government acknowledges, however, that if Telecom's UFB bid is successful, its copper network might offer a less effective competitive constraint on fibre. To mitigate this risk, copper access pricing will continue to be regulated. In Australia, the government incumbent Telstra settled heads of agreement with NBN Co in June 2010 under which it will receive A \$5 billion for reuse of its infrastructure including pits, ducts and backhaul fibre and $\mathrm{A} \$ 4$ billion to progressively migrate its customers from the copper and HFC cable networks to NBN Co's wholesale fibre network. (Rudd, Tanner \& Conroy, 2010) Unlike Tasmania, where the state- 
owned power utility's ducts and poles are being used where possible for fibre deployment, this means the FTTP deployment on the mainland will use existing telecoms distribution infrastructure.

In none of the four places do governments appear to be preventing anyone building competing fixed line infrastructure. The infrastructure strategies that incumbents decide to pursue as the publicly-funded open access networks are built and activitated are likely to be critical elements in the competitive landscape that evolves. The future of Telecom NZ's partly-completed FTTN 'cabinetisation' program is heavily dependent on outcome of UFB FTTP process. It has indicated that if it is not successful in securing the largest franchise, for metropolitan Auckland, it is not interested in any of the UFB moneys. In Australia, the utility provider in the national capital, Canberra, has an FTTN network already ('TransACT') and is upgrading it to FTTP. Despite its agreement with NBN Co, Telstra is taking the opportunity provided by the demolition of an exchange in inner city Brisbane to replace its copper network there with FTTP serving 18,000 customers. (Bingeman, 2010) In Alberta, there are a variety of companies that offer wholesale fibre access, and both Telus and cable company Shaw have started rolling out FTTP services in the province. Singtel has substantial fibre assets of its own.

\section{Plans outside the fibre footprint}

Plans for fibre access networks have attracted much of the public attention, but what is happening beyond the fibre footprints is also important in the three places where it is significant. Alberta is giving renewed attention to the last mile, acknowledging that a large number of communities with SuperNet POPs still do not have fixed or wireless access networks offering services that use the network to retail customers. The $25 \%$ of New Zealand households and businesses outside the 33 local fibre areas are being addressed in a 'separate process which may be associated with the review of Telecommunications Service Obligations'. Australia's NBN Co will run a separate tender like the ones $\mathrm{CFH}$ is running in New Zealand for the $4 \%$ of premises to be served by terrestrial wireless. It has developed plans for satellite services for the remaining $3 \%$. A \$250 million competitive backhaul network serving many major non-metropolitan centres currently served only by Telstra's backhaul network is being built by the successful tenderer, NextGen Networks.

\section{Funding and financial expectations}

Expectations about returns from the public investments in the four plans are different. In Singapore, the public funding does not appear to have been expressed as an investment but as a subsidy to the OpCo and NetCo, Open Net and Nucleus Connect. In Alberta, the public funding was expressed partly as a subsidy and partly as a long-term commercial contract for the provision of services to the Government of Alberta.

CFH in New Zealand is required to operate 'in a financially sustainable manner', to 'begin investing without providing a commercial return to the Crown' and to 'eventually provide a commercial return on the Crown's investment, and operate as a successful business, when directed by Shareholding Ministers and the Minister for Communications and Information 
Technology'. (CFH 2010a) CFH is able to accept a lower rate of return than other shareholders on equity in the local fibre companies in which it will hold stakes of up to $50 \%$. CFH cannot guarantee any rate of return to shareholders in these companies.

The Implementation Study into the Australian NBN set out options for equity and debt funding of the company's infrastructure plans. It forecast a return of between 3.6 per cent (for a scenario involving low demand, low wholesale price, a cost blowout and no sharing of ducts and poles scenario) and 8.3 per cent (with more positive assumptions). Authors McKinsey and KPMG thought 6-7 per cent was a reasonable estimate. No decisions have yet been taken on the structure of equity and/or debt funding for the whole project, although public funds committed so far are being treated as capital rather than expenditure in the national government's accounts.

\section{Local debates about models chosen and performance to date}

Debates about the appropriateness of the policy models chosen and their performance to date have been lively. Four related themes dominate. First, supporters and critics have disagreed about the nature and scale of the problems with existing broadband services. Second, they have disagreed about the immediate need for the kinds of speeds enabled by all-fibre networks. Third, the rapid rise of mobile broadband and the decline of fixed line voice telephony has led some to argue that public policy is being directed into an expensive solution to a problem that is better solved through other means. Finally, the process of determining the new policies has been criticized, especially the lack of robust cost-benefit analyses to allow proper consideration of different options and to weigh the proposed spending on broadband against public investment in other areas like health, education and other forms of infrastructure.

\section{Conclusions}

Only in Alberta and Singapore have significant parts of the proposed networks been built. The only one that has been operating for any length of time is the Alberta SuperNet. Attempting to assess its performance, it is important to understand that there are two quite separate customer groups using network: the Alberta government and the private sector. On the government side, the SuperNet appears to have been very effective in extending government services across the province, and in centralizing service delivery and telecommunications spending on a single network. Network users report that the quality of services offered over the SuperNet is excellent, and given that it brings fibre optic connectivity into 429 communities, there is capacity for expansion of next generation services over time. The contractual arrangements for building and operating the SuperNet are not in the public domain, making it difficult to assess the financial impacts of the SuperNet. The provincial government does not receive any revenues from the operation of the SuperNet, but has realized cost savings by delivering its services over the network.

The SuperNet has been less effective as an enabler of broadband connectivity to rural Alberta. The top-down, 'build it and they will come' approach to deploying the network has been widely 
criticized for failing to engage local communities. ${ }^{1}$ The private sector customers who would act as ISPs are hindered by the pricing structure, and by the lack of last mile connectivity. ${ }^{2}$ While competition for retail service provision is enabled by the SuperNet's open access network, there are also facilities-based competitors operating in the province. For instance, the incumbent telco, Telus, has extensive fibre assets, as do other operators. Providers that want to offer services to a particular region can choose to use the SuperNet, Telus, or other suppliers (e.g. Google), and may find it easier to deal with a single operator for middle mile and backhaul connections, rather than a combination of the SuperNet and another operator. Various stakeholders within the province are aware of the shortcomings in using the SuperNet to bridge Alberta's rural digital divide, and are taking action to improve the situation. In August 2010 the provincial government issued a Request for Information seeking advice on how to extend broadband services to rural and remote parts of the province (Service Alberta, 2010).

There are many unanswered questions about the approaches in the other three territories. It does not appear that Singapore's NGNBN is subject to any requirement to provide a direct return on investment for public funds invested in the NetCo and OpCo, and we are unaware of any costbenefit analysis conducted on the project. OpenNet does not have a monopoly on the fibre access network, so it is possible that competitors could duplicate this network. For example, although Singtel is one of four partners in OpenNet, it also has extensive fibre assets of its own and is thought to be laying further fibre at the same time as OpenNet is building the NGNBN. Access pricing is regulated and subject to regular review, but may not be sustainable at initial rates if services are delivered over competing fibre access networks. If access costs rise because there are fewer subscribers served than anticipated, the economics of providing service at the retail level may not be sustainable and competition may be diminished. Access seekers will only use the NGNBN if doing so makes commercial sense (BT, 2009).

At the operating level, Nucleus Connect does not have an exclusive arrangement with OpenNet, meaning that more than one operating company may enter the market. Indeed, 5 of 41 potential operators are already connected through OpenNet. This may result in vertical integration at the operating and retail levels, making it difficult for retail service providers who are purchasing access from Nucleus Connect to offer competitive services. While the NGNBN is structured in a way that eliminates vertical integration for those purchasing services from Nucleus Connect, it does not prevent other operating companies from contracting with OpenNet and vertically integrating their operations at layers 2 and 3. It is too early to assess whether the NGNBN will succeed in enabling sustainable competition at the retail layer (an objective because competition should ensure affordable, innovative services for consumers), but it is possible that by allowing competition at layers 1 and 2 the anticipated benefits of developing an open access network may not be realized.

\footnotetext{
${ }^{1}$ On these points see ABCtech Rural Broadband Working Group (2008), Alberta Council of Technologies (2010), Alberta SuperNet First Mile Rural Task Force (2008) and Taylor Warwick Consulting Limited (2010).

${ }^{2}$ Canada has an open access regime for the copper local loop. It seems that the complexities of dealing with the SuperNet and the telco incumbent Telus make it very difficult to provide residential broadband connections using the combination of SuperNet middle mile connectivity using the SuperNet and last mile access over the incumbent's copper local loop. The relationship between independent ISPs, Telus and the SuperNet has been the subject of various actions before the CRTC, Canada's telecommunications regulator.
} 
Progress to date suggests that the Singaporean approach will be effective in transitioning its national broadband infrastructure to a fibre access network, enabling gigabit connectivity to all premises. Retail service providers have already indicated that the NGNBN is more affordable than the previous access regime (Nucleus Connect, 2010), and it is anticipated that the separation of wholesale and retail operations will encourage competition among retail service providers. 


\section{Acknowledgement}

This research was supported by a Social Sciences and Humanities Research Council of Canada grant: Developing Next Generation Broadband Infrastructure: Learning from Australia's

National Broadband Network (Investigators: Catherine Middleton, Ryerson University, Canada, and Jock Given, Swinburne University of Technology, Australia). See

http://www.broadbandresearch.ca/nextgen for project details.

\section{References}

Alberta SuperNet (2006). Harnessing the SuperNet Advantage.

http://web.archive.org/web/20070824044237/http://www.albertasupernet.ca/the+project/n ews/SuperNet_Final.pdf. (accessed 11 May 2010).

Alberta SuperNet (2010a). What Does the SuperNet Do?

http://www.thealbertasupernet.com/what_is_the_supernet/what_does_supernet_do.html. (accessed 1 September 2010).

Alberta SuperNet (2010b). Become a Service Provider. http://www.thealbertasupernet.com/become_sp/become_sp.html. (accessed 3 September 2010).

Australian Bureau of Statistics. (2009). Internet Activity, Australia, December 2008, cat no 8153.0, ABS, Canberra (April).

Axia (2010). The Alberta SuperNet: An Axia NGN Solution Helps to Bridge the Digital Divide. Calgary: Axia. http://axia.com/documents/networks/Case\%20Study_SuperNet_np.pdf. (accessed 5 September 2010).

Bartholomeusz. S. 2009a, 'NBN numbers don't stack up', Business Spectator, 14 April.

-2009b, 'Hard choices for infrastructure', Business Spectator, 14 April.

-2009c, 'Long live the “New NBN”?', Business Spectator, 7 April.

Bingeman, M. (2010). 'Telstra move to close exchange worries rivals', The Australian, 3 September.

Australian Labor Party (ALP). (2007). New Directions for Communications: A Broadband Future for Australia - Building a National Broadband Network. Canberra: ALP (March).

Blanchard, C. (1995). Telecommunications regulation in New Zealand: light-handed regulation and the Privy Council's judgment. Telecommunications Policy, 19(6), 465-75.

Campbell, L.H. and Holmes, J.R. (2008) Regulating Service Providers' Access to an FTTN Network. Media International Australia, 127, 21-6.

Chorus. (2009) Enhancing the Broadband Network: http://www.chorus.co.nz/enhancing-thebroadband-network. (accessed 14 May 2009).

Commerce Commission (NZ). (2009). Telecommunications Overview: http://www.comcom.govt.nz/IndustryRegulation/Telecommunications/Overview.aspx (accessed 4 May 2009).

-(2008). Brief for Incoming Ministers. Wellington: Commerce Commission (November).

Conroy, Senator S. (Minister for Broadband, Communications and the Digital Economy) 2009, Joint Media Release with Prime Minister, Treasurer and Minister for Finance, New [NBN], 7 April.

Crown Fibre Holdings (CFH). (2010a). Statement of Intent 2009-13, May.

Crown Fibre Holdings (CFH). (2010b). 'CFH announces shortlist and negotiations for first stage roll-out of UFB', Media Release, 9 September. 
Fletcher, P. (2009). Wired Brown Land? The Battle for Broadband. Sydney: UNSW Press.

Gattung, T. (2010). Bird on a Wire: The Inside Story from a Straight Talking CEO. Auckland:

Random House.

iN2015 Infocomm Infrastructure Services and Technology Development Sub-Committee (2006). Totally Connected, Wired and Wireless. Singapore: IDA.

http://www.ida.gov.sg/doc/About\%20us/About_Us_Level2/20071005103551/09_Infocomm_Inf

rastructure_Services_and_Technology_Devt.pdf. (accessed 31 August 2010).

Infocomm Development Authority of Singapore (2006). Fact Sheet: Next Generation National Infocomm Infrastructure. http://www.itu.int/osg/spu/ngn/documents/NGNII-Factsheet-060303Singapore.pdf. (accessed 20 May 2010).

Infocomm Development Authority of Singapore (2009a). Ida Selects Starhub's Nucleus Connect as Next Gen NBN OpCo. http://www.ida.gov.sg/insg/post/IDA-selects-StarHubsNucleus-Connect-as-Next-Gen-NBN-OpCo.aspx. (accessed 1 September 2010).

Infocomm Development Authority of Singapore (2009b). Industry Structure for Effective Open Access. http://www.ida.gov.sg/Infrastructure/20090731125844.aspx. (accessed 16 March 2010).

Infocomm Development Authority of Singapore (2010a). Fact Sheet: Wireless@SG. http://www.ida.gov.sg/doc/News\%20and\%20Events/News_and_Events_Level2/2009072 8165354/WirelessSG_factsheet.pdf. (accessed 1 September 2010).

Infocomm Development Authority of Singapore (2010b). What Is the Next Generation Nationwide Broadband Network (Next Gen NBN)? http://www.ida.gov.sg/Infrastructure/20090717105113.aspx. (accessed 1 September 2010).

Key, J. (National Party Leader). (2008). Achieving a Step Change: Better Broadband for New Zealand. Leader's Speech. (22 April).

Ministry of Economic Development (MED), Resources and Networks Branch. (2001). New Zealand Telecommunications 1987-2001 (NZ Telecommunications Information Publication No 8). Wellington: MED (August).

New Zealand Government. (2010). 'Ultra-fast Broadband Initiative: Overview of Amendments', 8 July.

Nucleus Connect (2010). Nucleus Connect Commences Commercial Operations to Power Infinite Possibilities on Singapore's Nationwide Ultra High-Speed Fibre Network http://www.nucleusconnect.com/press-310810-Commencement.php. (accessed 1 September 2010).

OECD. (2009a). Broadband Portal. http://www.oecd.org/document/54/0,3343,en_2649_34225_38690102_1_1_1_1,00.html. (accessed 23 August, 21 December 2009)

OECD. (2009b). Communications Outlook. Paris: OECD.

OECD. (2009c). Economic Policy Reforms: Going for Growth. Paris: OECD.

OpenNet (2010). OpenNet Congratulates Nucleus Connect on Its Commercial Launch. http://www.opennet.com.sg/press-release/opennet-congratulates-nucleus-connect-on-itscommercial-launch/. (accessed 1 September 2010).

Ratcliffe, M. (2010). Address to the CommsDay Summit, Auckland, 18 May 2010.

Reynolds. T. (2009). The Role of Communications Infrastructure Investment in Economic Recovery, DSTI/ICCP/CISP(2009)1/FINAL, OECD, Paris (19 May). 
Rudd, K. (Prime Minister of Australia) and Swan, W. (Treasurer) 2009, Transcript of media conference at Parliament House, Canberra, 7 April.

Rudd, K. (Prime Minister of Australia), Tanner, L. (|Minister for Finance and Deregulation) and Conroy, S. (Minister for Broadband, Communications and the Digital Economy), 'Agreement between NBN Co and Telstra on the rollout of the National Broadband Network', Media Release, 20 June.

White, D. (2010). 'Special deal to slug city customers', Australian Financial Review, 8 September, p. 53.

Yang, L. B. (2008). Opening Remarks by Dr Lee Boon Yang at The Media Briefing for The Award of Next Generation National Broadband Network Netco Request-for-Proposal http://app.mica.gov.sg/Default.aspx?tabid=36\&ctl=Details\&mid=539\&ItemID=887. (accessed 1 September 2010). 
Table: Next Generation Broadband Plans - Alberta (Canada), Singapore, Australia, New Zealand

\begin{tabular}{|c|c|c|c|c|}
\hline Element & Alberta (Canada) & Singapore & Australia & New Zealand \\
\hline \multicolumn{5}{|l|}{$\begin{array}{l}\text { Population and } \\
\text { density }\end{array}$} \\
\hline $\begin{array}{l}\text { Population estimate } \\
\text { at } 5 \text { September } 2010\end{array}$ & 3.8 million & 5.1 million [June 2010] & 22.4 million & 4.4 million \\
\hline $\begin{array}{l}\text { Area [sq km] [US } 9.4 \\
\text { mill, Canada } 10.0 \\
\text { mill] }\end{array}$ & 662,000 & 710.3 [2009] & 7.7 million & 269,000 \\
\hline $\begin{array}{l}\text { Persons/sq km [US } \\
32.8, \text { Canada 3.4, } \\
2008]\end{array}$ & $5.7[2010]$ & 7,022 [2009] & $2.9[2008]$ & 15.9 [2008] \\
\hline $\begin{array}{l}\% \text { of landmass used } \\
\text { by cumulative } 50 \% \text { of } \\
\text { popn [US } 13.91, \\
\text { Canada } 15.91 \text { ] }\end{array}$ & $\mathrm{n} / \mathrm{a}$ & $\mathrm{n} / \mathrm{a}$ & 10.36 & 8.31 \\
\hline General description & $\begin{array}{l}\text { Large province of a huge } \\
\text { country. Around two-thirds of } \\
\text { population lives in two major } \\
\text { cities, Calgary and Edmonton. } \\
<20 \% \text { of the population lives in } \\
\text { multi-unit dwellings. }\end{array}$ & $\begin{array}{c}\text { Island city state. Densely } \\
\text { populated, } 85 \% \text { in multi-unit } \\
\text { dwellings. }\end{array}$ & $\begin{array}{l}\text { Island continent with small } \\
\text { number of offshore islands. } \\
\text { Sparsely populated overall but } \\
\text { high \% in cities dominated by } \\
\text { free-standing houses. Approx } \\
30 \% \text { live in multi-unit dwellings }\end{array}$ & $\begin{array}{l}\text { Two main islands with small } \\
\text { number of others. In } 2006, \\
55 \% \text { of households were in the } \\
\text { Auckland, Wellington and } \\
\text { Canterbury [Christchurch] } \\
\text { regions. }\end{array}$ \\
\hline \multicolumn{5}{|l|}{$\begin{array}{l}\text { Broadband } \\
\text { penetration }\end{array}$} \\
\hline $\begin{array}{l}\text { Number of subs [Dec } \\
\text { 2009] }\end{array}$ & $\begin{array}{c}1,091,000 \text { (estimate, } \sim 11 \% \text { of } \\
\text { Canadian total) }\end{array}$ & & $5,133,000$ & 992,000 \\
\hline $\begin{array}{l}\text { Fixed broadband } \\
\text { subs/100 inhabs, Dec } \\
2009 \text { [OECD] }\end{array}$ & $\begin{array}{l}29.6 \text { subs per } 100 \text { popn [Dec } \\
\text { 2009] } 11 / 30 \text { OECD }(\text { Canada })\end{array}$ & $\begin{array}{l}23.7 \text { subs per } 100 \text { popn [2009 } \\
\text { ITU data, non-OECD country] }\end{array}$ & $\begin{array}{l}23.3 \text { subs per } 100 \text { popn [Dec } \\
\text { 2009] 17/30 OECD }\end{array}$ & $\begin{array}{l}23.2 \text { subs per } 100 \text { popn [Dec } \\
\text { 2009] 18/30 OECD }\end{array}$ \\
\hline $\begin{array}{l}\text { Mobile broadband } \\
\text { subs per } 100 \\
\text { population, } 2009 \\
\text { (ITU) }\end{array}$ & 7.7 (Canada) & 89 & 67 & 64.2 \\
\hline
\end{tabular}




\begin{tabular}{|c|c|c|c|c|}
\hline Element & Alberta (Canada) & Singapore & Australia & New Zealand \\
\hline \multicolumn{5}{|l|}{ Broadband plans } \\
\hline Project & Alberta SuperNet & $\begin{array}{c}\text { Next Generation National } \\
\text { Broadband Network }\end{array}$ & National Broadband Network & $\begin{array}{l}\text { Ultra-Fast Broadband } \\
\text { Initiative }\end{array}$ \\
\hline Status & $\begin{array}{l}\text { Announced } 2001 . \\
\text { Network built } 2005 \text {. }\end{array}$ & $\begin{array}{l}\text { Announced } 2006 . \\
\text { Under construction. } \\
\text { First retail customers to be } \\
\text { connected late } 2010 .\end{array}$ & $\begin{array}{c}\text { Announced } 2009 . \\
\text { Under construction. [backhaul; } \\
\text { Tasmania; other trial sites; } \\
\text { further sites] } \\
\text { First retail customers connected } \\
\text { in Tasmania July } 2010 . \\
\text { August election returned } \\
\text { minority government dependent } \\
\text { on support of independents and } \\
\text { Green - construction timetable } \\
\text { being revised to give priority to } \\
\text { regional and rural areas }\end{array}$ & $\begin{array}{c}\text { Election policy } 2008 . \\
\text { Draft Plan March } 2009 . \\
\text { Overview and Invitation to } \\
\text { Participate, Sept/Oct } 2009 . \\
\text { Proposals received from } 18 \\
\text { different parties and consortia, } \\
\text { Jan 2010. } \\
\text { Amendments to Plan, July } \\
2010 . \\
14 \text { parties shortlisted for } \\
\text { further negotiation of which } 3 \\
\text { for 'prioritized negotiations', } \\
\text { Sept 2010. }\end{array}$ \\
\hline $\begin{array}{l}\text { Timeframe for } \\
\text { completion }\end{array}$ & $\begin{array}{c}\text { Complete } \\
\text { Final Mile Broadband Initiative } \\
\text { launched } 2010 \text { to extend rural } \\
\text { broadband coverage }\end{array}$ & $95 \%$ coverage by 2012 & 8 years -2018 & $\begin{array}{l}\text { 6-10 years - December } 2015 \\
\text { to December } 2019\end{array}$ \\
\hline \multicolumn{5}{|l|}{$\begin{array}{l}\text { Cost [exchange rates } \\
\text { at } 5 \text { September 2010] }\end{array}$} \\
\hline Total cost & $\begin{array}{c}\text { At least C } \$ 330 \text { million } \\
\text { including } \$ 100 \text { million by Bell } \\
\text { Canada for base area network } \\
\text { and } \$ 30 \text { million by Axia for } \\
\text { extended area network }\end{array}$ & $\begin{array}{l}\text { Up to } \mathrm{S} \$ 1 \text { billion invested by } \\
\text { government, private sector } \\
\text { investment unknown }\end{array}$ & A $\$ 43$ billion & At least NZ\$3 billion \\
\hline $\begin{array}{l}\text { Public cost, local } \\
\text { currency, \$US }\end{array}$ & $\begin{array}{l}\text { C\$200 million } \\
\text { US\$190 million }\end{array}$ & $\begin{array}{c}\text { S\$1 billion } \\
\text { US\$742 million }\end{array}$ & $\begin{array}{l}\text { A } \$ 43 \text { billion } \\
\text { US } \$ 39 \text { billion }\end{array}$ & $\begin{array}{l}\text { NZ\$1.5 billion } \\
\text { US } \$ 1 \text { billion }\end{array}$ \\
\hline $\begin{array}{l}\text { Public cost per head, } \\
\text { \$US }\end{array}$ & $\$ 51$ & $\$ 146$ & $\$ 1743$ & $\$ 244$ \\
\hline
\end{tabular}




\begin{tabular}{|c|c|c|c|c|}
\hline Element & Alberta (Canada) & Singapore & Australia & New Zealand \\
\hline \multicolumn{5}{|c|}{$\begin{array}{l}\text { What has been or } \\
\text { will be done }\end{array}$} \\
\hline Overview & $\begin{array}{l}\text { - } \quad \text { Fibre backbone to points of } \\
\text { presence in } 429 \\
\text { communities } \\
\text { - Fibre connections to } 4700 \\
\text { government service } \\
\text { providers in these } \\
\text { communities and urban } \\
\text { centres (provincial } \\
\text { government \& municipal } \\
\text { offices, schools \& colleges, } \\
\text { health facilities, libraries). } \\
\text { 'Last mile' connections to } \\
\text { citizens provided by the } \\
\text { private sector. } ~ 300 \\
\text { communities have at least } \\
\text { one ISP in } 2010 . \\
\text { Government of Alberta is an } \\
\text { anchor tenant across the } \\
\text { whole network - } 10 \text { year } \\
\text { contract with Axia for } \\
\text { carriage of services and } \\
\text { information over SuperNet. }\end{array}$ & $\begin{array}{c}\text { FTTP network to provide } \\
\text { broadband connectivity to all } \\
\text { homes and offices in Singapore, } \\
\text { supporting speeds of } 1000 \\
\text { Mbits/sec. Plans to develop and } \\
\text { deliver services (e.g. ehealth, } \\
\text { elearning, ecommerce, } \\
\text { entertainment) over network. }\end{array}$ & $\begin{array}{c}\text { FTTP, } 100 \text { Mbits/sec, } 93 \% \\
\text { of homes, schools, } \\
\text { workplaces - generally } \\
\text { towns with populations } \\
\text { bigger than } 1000 \text {. NBN Co } \\
\text { proposes to focus on Layer } 2 \\
\text { services } \\
\text { - Terrestrial wireless, } 4 \% \text { of } \\
\text { homes and businesses, peak } \\
\text { speed } 12 \text { Mbits/sec - } \\
\text { separate contract will be let } \\
\text { Satellite, peak speed } 12 \\
\text { Mbits/sec, remaining } 3 \%\end{array}$ & $\begin{array}{c}\text { - FTTP to } 75 \% \text { of New } \\
\text { Zealanders } \\
\text { - Local fibre companies } \\
\text { (LFCs) must provide Layer } \\
2 \text { services across all parts of } \\
\text { network plus Layer } 1 \text { point- } \\
\text { to-point services } \\
\text { (particularly suitable for } \\
\text { business customers) to end- } \\
\text { users seeking premium } \\
\text { quality services (likely up } \\
\text { to } 1 \text { Gbps) } \\
\text { - Until Dec } 2019 \text {, LFCs reqd } \\
\text { to supply services on non- } \\
\text { discriminatory basis. After } \\
\text { Dec } 2019, \text { LFCs required to } \\
\text { provide unbundled access } \\
\text { to Layer } 1 \text { point-to-point } \\
\text { services on 'equivalence of } \\
\text { inputs' basis } \\
\text { Remaining } 25 \% \text { addressed } \\
\text { in 'separate process which } \\
\text { may be associated with the } \\
\text { review of } \\
\text { Telecommunications } \\
\text { Service Obligations' }\end{array}$ \\
\hline
\end{tabular}




\begin{tabular}{|c|c|c|c|c|}
\hline Element & Alberta (Canada) & Singapore & Australia & New Zealand \\
\hline Priorities & $\begin{array}{l}\text { Initially } \\
\text { Improving rural broadband } \\
\text { access } \\
\text { Making government services } \\
\text { and information available online } \\
\text { Now } \\
\text { Improving rural broadband } \\
\text { access by increasing the number } \\
\text { of communities with 'last mile' } \\
\text { connections to the SuperNet } \\
\text { Increasing use of the SuperNet }\end{array}$ & $\begin{array}{l}\text { Network available to } 60 \% \text { of } \\
\text { homes and offices by end of } \\
2010 \text {. } \\
\text { Next Gen Services Innovation } \\
\text { Programme to develop new } \\
\text { broadband services and } \\
\text { applications (initial apps } \\
\text { available by end of 2010) }\end{array}$ & $\begin{array}{c}\text { Tasmania [island province], } \\
\text { in conjunction with state } \\
\text { government and power } \\
\text { utility } \\
\text { - Fibre backhaul between } \\
\text { major non-metro centres } \\
\text { [A } \$ 250 \text { million] } \\
\text { - Initially - otherwise roll-out } \\
\text { simultaneously in metro, } \\
\text { regional and rural areas. } \\
\text { Post-election, 'outside-in' } \\
\text { timetable giving greater } \\
\text { priority to regional and rural } \\
\text { areas. }\end{array}$ & $\begin{array}{c}\text { - Businesses, schools and } \\
\text { health services; greenfields } \\
\text { developments and some } \\
\text { tranches of residential users } \\
\text { within } 6 \text { years } \\
\text { - } 75 \% \text { of population within } \\
10 \text { years }\end{array}$ \\
\hline Structure & $\begin{array}{c}\text { Base area [urban] network } \\
\text { funded, owned and } \\
\text { operated by Bell [private]. } \\
\text { 'Extended area' network in } \\
402 \text { rural communities } \\
\text { [owned by GoA] and } \\
\text { operated by Axia [private]. } \\
\text { Axia sells Layer } 2 \text { or } 3 \\
\text { wholesale services to } \\
\text { private sector service } \\
\text { providers. } \\
\text { Axia does not offer retail } \\
\text { services but acts as the } \\
\text { GoA's 'service provider', } \\
\text { delivering its services and } \\
\text { information to the } \\
\text { government service } \\
\text { providers. }\end{array}$ & $\begin{array}{c}\text { PPP } \\
\text { 3-level pyramid: } \\
\text { NetCo: OpenNet (Shareholders } \\
\text { Axia [private], SingTel [state- } \\
\text { controlled]), Singapore Press } \\
\text { Holdings, and Singapore Power } \\
\text { Telecommunications). OpenNet } \\
\text { owns the fibre. } \\
\text { OpCo: Nucleus Connect } \\
\text { (shareholder: StarHub) activates } \\
\text { the fibre. } \\
\text { Retail Service Providers (e.g. } \\
\text { M1, SingTel, StarHub, } \\
\text { SuperInternet) buy access from } \\
\text { Nucleus Connect at prices } \\
\text { approved by the Infocomm } \\
\text { Development Authority. }\end{array}$ & $\begin{array}{l}\text { - Government establishes new } \\
\text { state-owned corporation, } \\
\text { holds majority of shares, } \\
\text { private investors hold rest - } \\
\text { Implementation Study later } \\
\text { recommends government } \\
\text { hold all shares during } \\
\text { construction } \\
\text { Corporation builds and } \\
\text { operates wholesale FTTP } \\
\text { network } \\
\text { Corporation has no retail } \\
\text { operations }\end{array}$ & $\begin{array}{c}\text { - Government establishes } \\
\text { Crown-owned investment } \\
\text { company, Crown Fibre } \\
\text { Holdings [CFH] } \\
\text { - CFH invests alongside } \\
\text { private investors in local } \\
\text { fibre companies offering } \\
\text { wholesale dark fibre to } \\
\text { service providers } \\
\text { - Local fibre companies have } \\
\text { no retail operations, though } \\
\text { non-controlling } \\
\text { shareholders may }\end{array}$ \\
\hline
\end{tabular}




\begin{tabular}{|c|c|c|c|c|}
\hline Element & Alberta (Canada) & Singapore & Australia & New Zealand \\
\hline Finance & $\begin{array}{c}\text { Base area [urban] network } \\
\text { funded [\$100 million], } \\
\text { owned and operated by } \\
\text { Bell. } \\
\text { Extended area [rural] } \\
\text { network funded by } \\
\text { Government of Alberta } \\
\text { [\$200 million] and Axia } \\
{[\$ 30 \text { million]. }}\end{array}$ & $\begin{array}{l}\text { Government grant of up to } \\
\text { S\$750 million to OpenNet to } \\
\text { build passive fibre network, and } \\
\text { up to } \$ 250 \text { million to Nucleus } \\
\text { Connect to build and operate } \\
\text { active infrastructure. }\end{array}$ & $\begin{array}{c}\text { - } 50 / 50 \text { debt/equity, } \\
\text { government holds } 51 \% \text { of } \\
\text { equity (approx } \$ 11 \text { billion) } \\
\text { government equity from } \\
\text { existing A } \$ 4.7 \text { billion } \\
\text { allocation plus } \$ 6.3 \text { billion } \\
\text { Infrastructure Bonds issued } \\
\text { to households and } \\
\text { institutions } \\
\text { - 'Significant private } \\
\text { investment is anticipated'. } \\
\text { Later Implementation Study } \\
\text { says likely rate of return } \\
\text { insufficient for private } \\
\text { investors } \\
\end{array}$ & $\begin{array}{c}\text { - CFH wholly owned by } \\
\text { national government. Local } \\
\text { fibre companies owned up } \\
\text { to } 50 \% \text { by CFH, rest by } \\
\text { private shareholders and /or } \\
\text { local government } \\
\text { - CFH may accept lower rate } \\
\text { of return than other } \\
\text { shareholders on equity in } \\
\text { local fibre companies, but } \\
\text { cannot guarantee any rate } \\
\text { of return }\end{array}$ \\
\hline Future & $\begin{array}{l}\text { Long term contracts in place } \\
\text { between government and Axia. } \\
\text { Efforts are ongoing to increase } \\
\text { private sector use of the } \\
\text { SuperNet, especially to provide } \\
\text { broadband to rural/remote users. }\end{array}$ & $\begin{array}{l}\text { Competition expected at the } \\
\text { active layer, Nucleus Connect } \\
\text { will not be the only OpCo. }\end{array}$ & $\begin{array}{c}\text { Government sells down } \\
\text { shareholding in NBN Co } \\
\text { within } 5 \text { years after network } \\
\text { built and operational, } \\
\text { 'consistent with market } \\
\text { conditions and national and } \\
\text { identity security } \\
\text { considerations' } \\
\text { Post-election - construction } \\
\text { schedule being revised to } \\
\text { give greater priority to } \\
\text { regional and rural areas. }\end{array}$ & $\begin{array}{l}\text { All CFH funds need not be } \\
\text { committed at the outset. Can } \\
\text { consider staged proposals and } \\
\text { reserve funds for future } \\
\text { rounds. }\end{array}$ \\
\hline
\end{tabular}

